Adam Sejbuk CM

(1) https://orcid.org/0000-0001-6936-3027

\title{
Święta Katarzyna Labouré oczami swoich biografów
}

(di) https://doi.org/10.15633/9788374389778.03

Katarzyna Labouré zmarła 31 grudnia 1876 roku. Tego samego dnia wieczorem oficjalnie ujawniono wspólnocie Sióstr Miłosierdzia jej tożsamość jako wizjonerki z rue du Bac. Aż dotąd imię tej, która spotkała Niepokalaną, było znane jedynie w dość wąskim kręgu sióstr i misjonarzy św. Wincentego a Paulo. Moment ten rozpoczął zatem nowy etap w historii recepcji objawień z 1830 roku, włączając w nią na stałe postać Katarzyny.

\section{Pierwsza opublikowana biografia}

Pierwsza biografia Katarzyny z 1877 roku pióra siostry Marie-Anne de Geoffre de Chabrignac powstała tylko do użytku wewnętrznego dwóch Zgromadzeń św. Wincentego a Paulo ${ }^{1}$. W 1878 roku misjonarz ks. Jules Chevalier, opierając się m.in. na zawartych w niej informacjach oraz na rękopisach wizjonerki, opublikował życiorys Katarzyny oraz szczegóły wszystkich trzech objawień Niepokalanej². Biograf korzystał również z informacji zawartych w Notice historique ${ }^{3}$ - pierwszej historii Cudowne-

1 Ta obszerna nota biograficzna ukazała się drukiem w styczniu 1878.

2 [J. Chevalier], La Médaille miraculeuse. Origine - histoire - diffusion - résultats, par M. Aladel, [9ème] édition revue et augmentée, Paris 1878.

3 Chodzi o najbardziej znaną publikację dotyczącą historii Cudownego Medalika: Notice historique sur l'origine et les effets d'une nouvelle Médaille en l'honneur de l'Immaculée Conception de la très Sainte Vierge Marie, généralement connue sous le nom de la Médaille miraculeuse, 1ère édition, Paris 1834. W sumie w latach 1834-1842 autor opublikował osiem wydań swojej 
go Medalika napisanej i wydanej w 1834 roku przez ks. Jean-Marie Aladela, spowiednika wizjonerki. To ważne dzieło wymagało jednak uzupełnień, ponieważ nie ujawniało tożsamości Katarzyny i wielu szczegółów związanych z objawieniami, a ponadto zostało wydane anonimowo. Biografia opracowana przez Chevaliera uzupełnia te luki i, co więcej, ukazuje się pod nazwiskiem Aladela, stanowiąc tym samym zaktualizowaną wersję Notice.

Praca Chevaliera składa się z dziewięciu rozdziałów, z których początkowy stanowi pierwszą oficjalnie opublikowaną biografię Katarzyny Labouré. We wstępie Chevalier wyjaśnia:

Niedawna śmierć siostry, która otrzymała objawienia Najświętszej Dziewicy, wzbudziła silne pragnienie, aby dzieło to zostało ponownie wydane. Wielu już niecierpliwi się, by je przeczytać i zapoznać się z pochodzeniem Cudownego Medalika. Wielu innych ma nadzieję, że odkryją nowe, nieznane dotąd, szczegóły. Wychodząc naprzeciw tym właśnie oczekiwaniom, podjęto decyzję o niniejszej publikacji ${ }^{4}$.

Chevalier przedstawia także uwagi na temat poprzednich wydań książki Aladela, zwracając uwagę na konieczność ich uzupełnienia:

Poprzednie wydania przedstawiają jedynie bardzo zwięzłe podsumowanie objawień Najświętszej Maryi Panny w 1830 roku. Poważne powody skłoniły ks. Aladela do pominięcia wielu rzeczy. Przede wszystkim bał się on zwrócić uwagę na postać pokornej siostry, która przekazała mu rozkazy z nieba i która miała pozostać w ukryciu do końca życia. Dziś obawy te nie mają już podstaw i, ku zbudowaniu wiernych, wolno opublikować wszystko to, co powiedziała siostra, a przynajmniej to, co zachowało się z jej przekazów 5 .

Chevalier zdaje sobie sprawę z różnic, jakie istnieją między wersją objawień przedstawionych przez Aladela a relacjami samej Katarzyny. Jego

Notice. W żadnym z nich tożsamość wizjonerki nie została ujawniona, a przebieg objawień przedstawiono schematycznie, pomijając zwłaszcza pierwsze objawienie z lipca 1830 roku oraz wizję Maryi z globem.

4 [J. Chevalier], La Médaille miraculeuse, dz. cyt., s. 3.

5 Tamże, s. 4. 
praca przedstawia nie tylko „nowe, nieznane dotąd szczegóły”, ale ma także charakter studium krytycznego, w którym historia rozpowszechnionego już Cudownego Medalika zostaje skonfrontowana z biografią i rękopisami samej Katarzyny. Te ostatnie dotyczą zwłaszcza pierwszego objawienia z lipca 1830 roku oraz wizji Maryi z globem. $Z$ dwóch powodów mamy tutaj do czynienia ze szczególnie istotnym źródłem: po pierwsze nigdy wcześniej nie zaprezentowano publicznie historii objawień opisanej przez samą Katarzynę, po drugie, Chevalier znał wizjonerkę osobiście i otrzymywał od niej „szczególnie konfidencjonalne wyznania”“, o czym zaświadczył w trakcie jej procesu beatyfikacyjnego.

Praca Chevaliera składa się z trzech głównych części: biografii Katarzyny, rekonstrukcji przebiegu objawień oraz świadectw łask otrzymanych przez wstawiennictwo Matki Bożej. Wniosła ona niezaprzeczalny wkład w rozpowszechnianie historii mariofanii z rue du Bac, oficjalnie wprowadzając do niej imię Katarzyny oraz oddając, paradoksalnie dopiero po śmierci, głos samej wizjonerce. Publikacja ta stanowi także nowe odczytanie teologicznego przesłania z rue du Bac, łącząc je z innymi objawieniami (La Salette, Lourdes, Pontmain), kultem maryjnym, jak również historią XIX wieku, szczególnie w okresie wojen pruskich i Komuny Paryskiej.

\section{Przygotowanie do wypełnienia misji}

Chevalier, opisując w pierwszym rozdziale życie Katarzyny, ukazuje cnoty, które przygotowywały ją do wypełnienia misji powierzonej jej podczas objawień. Część biograficzna rozpoczyna się wstępem, w którym przedstawione zostają trudności, jakie czytelnik może napotkać w zrozumieniu życiorysu Katarzyny. Chodzi o kontrast pomiędzy prostotą jej zwyczajnego życia a niezwykłymi łaskami, którymi została napełniona. Autor przypomina, że Bóg nie osądza po pozorach i tym, co kocha ponad wszystko, „jest prostota i czystość [...]. Ukazuje swoją mądrość i moc, używając tego, co słabe, do wielkich rzeczy"7. Oto wyjaśnienie i podsumowanie życia Katarzyny - prostej burgundzkiej kobiety i zarazem mistyczki.

6 Archives des Filles de la Charité, Paris (AFCP), Procès de béatification, Déposition de J. Chevalier, s. 123. Zob. R. Laurentin, Catherine Labouré et la Médaille miraculeuse, t. 2: Procès de Catherine (1877-1900), Paris 1979, n 877, s. 195. 
Jak każda biografia, także ta pióra Chevaliera rozpoczyna się od daty i miejsca urodzin bohaterki: 2 maja 1806 roku w Fain-lès-Moutiers. Według autora już mała ojczyzna Katarzyny, Côte-d’Or w Burgundii, zostałą przesiąknięta świętością związanych z nią wielkich postaci: św. Bernarda, św. Wincentego a Paulo i św. Joanny de Chantal. Rodzina Labouré została przedstawiona jako wzorcowa: „jej rodzice, szczerzy chrześcijanie, żyli godnie, uprawiając swoją własność i oddając się pracy oraz prostocie życia z łatwością typową dla ludności wiejskiej"8. Jednak pierwsza część biografii przywołuje także bolesne wydarzenia - Katarzyna bardzo wcześnie traci matkę. Według autora „Bóg odebrał ją dziewczynce, zanim skończyła ósmy rok. Już wtedy, w brzemieniu tej ofiary, Katarzyna czuła, że Najświętsza Dziewica chce być jej jedyną Matką" . Późniejsza tradycja dodaje, że po tej stracie dziecko wspięło się na krzesło i pocałowało figurę Najświętszej Maryi Panny, „prosząc ją o zastąpienie dobrej matki, którą właśnie straciło"10. Przyszła wizjonerka musi również przejąć pieczę nad domem rodzinnym i zadbać o prace domowe. Chevalier tak charakteryzuje Katarzynę w okresie przed wstąpieniem do Zgromadzenia:

Jej młodość pokazuje nam, że jest już skromna w stroju i cechuje się powagą charakteru; pobożna i skupiona w kościele parafialnym, dokąd pilnie uczęszcza; można ją było zobaczyć klęczącą na zimnych kostkach brukowych nawet w zimie. Nie było to zresztą jedyne umartwienie jakie praktykowała: od najmłodszych lat do zmęczenia pracą dodawała zwyczaj poszczenia w piątki i soboty nawet bez wiedzy ojca ${ }^{11}$.

I dalej:

W ten sposób wyraźnie zarysowują się cechy charakteru przyszłej siostry - jej zalety i wady. Z jednej strony widzimy prawdziwą prostotę, bez zbędnych starań, realizującą się w najbardziej pracochłonnych obowiązkach, okrytą niewinnością i żarliwością, z drugiej, charakter

8 Tamże, s. 3.

9 Tamże. W rzeczywistości Matka Katarzyny umiera w 1815 roku, gdy ta ma 9 lat.

10 Zob. R. Laurentin, Vie de Catherine Labouré. Voyante de la rue du Bac et servante des pauvres 1806-1876, t. 2: Preuves, Paris 1980, s. 37. R. Laurentin, Vie de Catherine Labouré. Voyante de la rue du Bac et servante des pauvres 1806-1876, t. 1: Récit, Paris 1980, s. 19.

11

[J. Chevalier], La Médaille miraculeuse, dz. cyt., s. 5 . 
przyzwyczajony do dominowania, za pomocą którego będzie musiała walczyć o przychylność ${ }^{12}$.

Te dwa cytaty dobrze oddają styl biografii Chevaliera. Autor przedstawia życie Katarzyny jako przygotowanie do jej dalszej misji, która łączy niezwykłą duchowość z prostą pracą Siostry Miłosierdzia. Zatem z jednej strony antycypuje fakt objawień, z drugiej zaś krytykę charakteru Katarzyny:

Nie należy jednak wierzyć, że siostra Katarzyna urodziła się z lekkim i łagodnym usposobieniem, że posłuszeństwo było dla niej całkiem naturalne. Nie, wręcz przeciwnie, była uparta i miała bardzo żywy temperament [...]. Znając tę naturę, możemy przypuszczać, że wypełniając swoją misję, musiała cierpieć z powodu przeciwności, jakich doświadczyła ${ }^{13}$.

Drogę prowadzącą do odkrycia powołania Siostry Miłosierdzia Chevalier ilustruje jeszcze innym wydarzeniem. Pewnej nocy, Katarzyna, zmagając się z myślami o zostaniu siostrą, ma sen. Jest w swoim kościele. Starszy ksiądz przygotowuje się do mszy. Pod koniec nabożeństwa woła ją, ale ona ze strachu ucieka. Jadąc do chorego, spotyka go ponownie. Słyszy: „Moja córko, dobrze jest zajmować się chorymi. Teraz uciekasz ode mnie, ale pewnego dnia będziesz szczęśliwa, że do mnie przyjdziesz. Bóg ma dla ciebie plan, nie zapominaj o tym"14. Wkrótce potem Katarzyna zostaje wysłana do Châtillon-sur-Seine, aby nauczyć się czytać i pisać. Tam, w domu Sióstr Miłosierdzia, odkrywa portret starszego kapłana ze swojego snu św. Wincentego a Paulo, współzałożyciela Zgromadzenia.

Publikując biografię Katarzyny, Chevalier po raz pierwszy sytuuje objawienia w kontekście nieznanego do tej pory życia wizjonerki. Jego głównym celem było przedstawienie objawień Cudownego Medalika w powiązaniu z historią życia Katarzyny. Śmierć jej matki i wybór Maryi jako nowej Matki zapowiadają późniejsze spotkanie obu kobiet podczas objawień, a sen o św. Wincentym pozwala zrozumieć powołanie do służby ubogim we wspólnocie. Tych kilka stron poświęconych jej młodości wypełnia przede wszystkim poczucie obecności Bożej Opatrzności, która prowadzi i strzeże Katarzynę,

12 Tamże, s. 6.

13 Tamże, s. 34 .

14 Tamże, s. 7. 
pomimo bolesnego doświadczenia straty oraz zastrzeżeń ojca co do jej powołania. Autor przedstawia te wydarzenia jako swego rodzaju przedmowę do dalszej historii i wytycza w ten sposób drogę prowadzącą do miejsca objawień - kaplicy w Domu Macierzystym Zgromadzenia Sióstr Miłosierdzia w Paryżu, do którego Katarzyna wstępuje 21 kwietnia 1830 roku $^{15}$.

\section{Pamięć o Katarzynie}

Chevalier również jako pierwszy publikuje zapiski Katarzyny, pozwalając tym samym poznać jej sposób wyrażania się. Nie tylko obficie cytuje siostrę, ale także komentuje jej rękopisy i samą ich formę. Poprawia pisownię, równocześnie oceniając język jako nieco naiwny ${ }^{16}$. Raz jest biografem i pisarzem, raz badaczem, historykiem i teologiem, co sprawia, że jego dzieło łączy w sobie faktografię z elementami fabularyzującymi.

Chevalier przywołuje rękopisy Katarzyny według chronologii opisywanych wydarzeń, a nie powstawania tekstów, i w ten sposób rekonstruuje historię życia wizjonerki oraz przebieg objawień Niepokalanej ${ }^{17}$. Zaskakujące może się wydawać, jak niewielką część biografii stanowi opis samych objawień. Niemniej jednak autor poświęca im osobny rozdział, aby przytoczyć fakty nieznane dotąd z publikacji Aladela i odpowiednio je skomentować ${ }^{18}$.

Chronologicznie pierwszym wydarzeniem opisanym przez Katarzynę, a przywołanym przez Chevaliera w części biograficznej, było przeniesienie relikwii św. Wincentego w kwietniu 1830 roku. Właśnie wizje serc św. Wincentego pozwoliły Chevalierowi przedstawić pierwsze zapiski Katarzyny:

Doznałam pocieszenia, widząc jego serce nad małym relikwiarzem, gdzie wystawione są jego relikwie. Objawiało mi się ono przez trzy dni z rzędu

15 Por. tamże, s. 9.

16 „Niech wyrazi to za pomocą swojego naiwnego języka” - pisze. Tamże, s. 11.

17 Część biograficzna jego pracy jest właściwie narracyjna, ale znajdują się tam również komentarze o charakterze historyczno-krytycznym: „Znajdujemy tę pojedynczą przysługę w liście napisanym przez Siostrę Katarzynę w 1856 roku, zgodnie z poleceniem udzielonym jej przez ks. Aladela”, komentuje Chevalier. Albo dalej: „Jeśli mamy wierzyć notatkom, które Siostra Katarzyna później napisała na polecenie ks. Aladela”. Tamże, s. 13.

18 Chodzi o rozdział trzeci. Naszym celem nie jest tu jednak analiza objawień, dlatego skoncentrujemy się jedynie na części biograficznej, kierując się strukturą publikacji Chevaliera. 
za każdym razem w inny sposób: najpierw białe, w kolorze cielistym, które zwiastowało pokój, ukojenie, niewinność i zjednoczenie. Potem zobaczyłam je w kolorze ognia, który był symbolem miłosierdzia rozpalającego się w sercach. Wydawało mi się, że to miłosierdzie trzeba odnowić i rozszerzyć aż na krańce świata. W końcu ukazało mi się czerwono-czarne, co zasmuciło moje serce ${ }^{19}$.

Następnie Chevalier przechodzi do wizji Chrystusa w Eucharystii, tym samym przedstawiając inne, nieznane dotąd doświadczenie duchowe Katarzyny:

Jeśli mamy wierzyć notatkom, które Siostra Katarzyna napisała później na polecenie ks. Aladela, ta pokorna dziewczyna przez cały czas swego seminarium cieszyła się odkrytym dla wzroku widokiem Tego, którego obecność jest ukryta przed naszymi zmysłami w sakramencie miłości. „Z wyjątkiem momentów” - jak powiedziała - „gdy miałam wątpliwości”"20.

Chevalier wprowadza też nowe źródła, nie tylko zapiski Katarzyny dotyczące objawień Matki Bożej, ale też jej notatki i modlitwy, dokumenty z procesu kanonicznego z 1836 roku oraz, co interesuje nas najbardziej w kontekście pierwszej opublikowanej biografii, świadectwa Sióstr Miłosierdzia o jej życiu. Te ostatnie będą ważnym elementem w przyszłym procesie beatyfikacyjnym. Chevalier obszernie cytuje siostry, które po śmierci Katarzyny opowiadają o jej życiu i na nowo odczytują minione wydarzenia, co pozwala prawidłowo zinterpretować biografię wizjonerki. Katarzyna wychodzi zatem z cienia głównie dzięki świadkom jej życia i ich opowiadaniom. I tak jak Cudowny Medalik potrzebował pośrednika w osobie ks. Aladela, tak historia życia Katarzyny potrzebowała wspomnień Zgromadzenia Sióstr Miłosierdzia.

Jedna z sióstr opowiada:

Spędziwszy sześć lat z siostrą Katarzyną i pracując z nią nieprzerwanie przez rok, wydaje mi się, że mogłabym przytoczyć wiele interesujących i budujących szczegółów, ale muszę przyznać, że jej życie było tak proste,

19 Tamże, s. 12.

20 Tamże, s. 13. 
tak jednolite, że nie znajduję nic godnego zauważenia. Pomimo dyskretnych zapewnień, że to ona jest siostrą uprzywilejowaną wizytami Najświętszej Maryi Panny, nie wierzyłam w to - jej życie było tak podobne do życia innych ${ }^{21}$.

Świadectwo to zawiera w sobie sedno przesłania biografii Chevaliera: Katarzyna po przeżyciu niezwykłego doświadczenia duchowego wciąż była podobna do innych Sióstr Miłosierdzia. W 1831 roku została powołana do pracy w hospicjum w Enghien, gdzie mieszkała przez czterdzieści sześć lat aż do śmierci. Jej pierwsza przełożona zaświadcza:

To była dobra starsza siostra, która każdego roku pragnęła, aby pierwsze owoce $z$ ogrodu trafiały do potrzebujących rodzin na przedmieściach lub do starszych mężczyzn, którymi się opiekowała. Siostry mogły je dostać, ale dopiero po nich ${ }^{22}$.

To właśnie tego typu wspomnienia będą stanowić główną oś biografii Katarzyny, także w powiązaniu z wydarzeniami historycznymi. Siostra Dufès opowiada, w jaki sposób Katarzyna uspokajała ją w trudnym dla Sióstr Miłosierdzia czasie Komuny Paryskiej:

W czasie Komuny oznajmiła mi, że wyjdę z domu w towarzystwie takiej a takiej siostry i że wrócę 31 maja. Zapewniała mnie, że nie mam się czego bać, bo Najświętsza Dziewica zajmie moje miejsce i zaopiekuje się domem. Nie przywiązywałam wtedy zbytniej wagi do słów tej dobrej siostry ${ }^{23}$.

Dopiero z perspektywy czasu siostra Dufès zrozumiała, że ta pokorna i pracowita siostra cieszy się niezwykłą opieką Niepokalanej. Pokora stanowi zresztą cnotę najczęściej przypisywaną Katarzynie:

„Siostra obowiązku i pracy” - powiedziała jej ostatnia przełożona - „ale przede wszystkim pokorna. Siostra Katarzyna była szczególnie doceniana przez tych, którzy byli na tyle blisko, aby rozpoznać wszystko to, co

\footnotetext{
21 Tamże, s. 30.

22 Tamże, s. 28-29.

23 Tamże, s. 39.
} 
pochodziło z prostoty, sprawiedliwości i czystości przenikających jej duszę, umysł, serce i całą osobę" ${ }^{24}$.

Znaczna część tej biografii została utkana ze wspomnień sióstr. Ostatecznie to żywa pamięć wspólnoty pomogła autorowi odtworzyć wydarzenia równoległe do rozprzestrzeniania się Cudownego Medalika, ale do tej pory nieznane. Ten aspekt jest zresztą charakterystyczny dla całej recepcji objawień z rue du Bac: ponowne odczytywanie wydarzeń z przeszłości, poszerzonych o nowe nieznane dotąd elementy, aktualizuje historię objawień. Dzięki publikacji Chevaliera, ujawnieniu tożsamości wizjonerki i przedstawieniu nieznanych dotąd szczegółów trzech mariofanii z 1830 roku, możliwa stała się ich reinterpretacja. Analogiczny proces można dostrzec także w samej wspólnocie Sióstr Miłosierdzia - ujawnienie tożsamości Katarzyny jako wizjonerki z rue du Bac, pozwala im spojrzeć na jej życie z innej perspektywy. Siostry zaczynają przypominać sobie epizody z życia Katarzyny dotyczące objawień, ale interpretują je w nowy sposób. Tym samym Chevalier, oddając głos współsiostrom, prezentuje z jednej strony sylwetkę Katarzyny, która była dyskretnym świadkiem rozpowszechniania się orędzia Matki Bożej, z drugiej strony wskazuje na tworząca się powoli interpretację jej postaci we wspólnocie Sióstr Miłosierdzia.

Chcąc podkreślić obie te role, Chevalier przywołuje między innymi epizod, kiedy Katarzyna poszła zobaczyć obrazy przedstawiające objawienia umieszczone w Domu Macierzystym. Ks. Aladel postarał się dyskretnie, aby siostra pozornie przez przypadek przyszła je zobaczyć w dniu i o godzinie, w której on się tam znajdował. Jednak u jednej z sióstr domowniczek zrodziły się pewne podejrzenia, kiedy spotkała tam Katarzynę. Odwracając się nagle do Ojca, powiedziała: „To z pewnością ta siostra, która miała wizje!". Ksiądz, bardzo zawstydzony, nie wiedząc, jak wybrnąć z tej niezręcznej sytuacji, pozostawił odpowiedź Katarzynie. Ta roześmiała się, mówiąc: „Naprawdę, rzeczywiście ją spotkałam!”, a zrobiła to z taką prostotą, że od razu pozbawiła siostrę podejrzeń: „O! widzę, że to nie ona. Nie poprosiłby jej Ksiądz, żeby mi to powiedziała”25.

To krótkie wspomnienie, na nowo odczytane po śmierci Katarzyny, pozwoliło Chevalierowi przedstawić główny rys duchowej tożsamości wizjo-

24 Tamże, s. 29.

25 Por. tamże, s. 26. 
nerki z rue du Bac: „Na pierwszy rzut oka” - pisze biograf - „wszyscy wierzyli, że potrafią odczytać głębię tej jakże prostej natury, ale ona wiernie strzegła Bożych tajemnic" ${ }^{26}$. Zewnętrzna prostota Katarzyny stanowiła ochronę dla jej niezwykłych duchowych doświadczeń.

Chevalier przywołuje także inne anegdoty sióstr o życiu Katarzyny. Przełożona z Enghien opowiada, że pewnego roku 8 grudnia w uroczystość Niepokalanego Poczęcia Katarzyna potknęła się i zwichnęła nadgarstek. Jednak nie powiedziała ani słowa tak, żeby nikt niczego nie zauważył. Później siostra Dufès, widząc, jak trzyma rękę zawiniętą w chustkę, zapytała ją, co się stało: „Ach! moja Siostro” - odpowiedziała cicho - „trzymam mój prezent od Najświętszej Panny, Ona każdego roku posyła mi jeden tego typu"27.

Kończąc biografię Katarzyny, Chevalier przywołuje jedno ze wspomnień odnoszących się do wieczoru jej śmierci:

Bardzo żywe wzruszenie wypełniło wtedy nasze serca - opowiada pewna siostra - wydawało się, że uczestniczyliśmy w niebiańskim spotkaniu naszej błogosławionej towarzyszki z tak dobrym Bogiem, który tyle razy objawiał się jej podczas seminarium, z Najświętszą Dziewicą tak piękną, że nic na ziemi nie mogłoby nakreślić Jej obrazu ${ }^{28}$.

Jako podsumowanie życiorysu Katarzyny, autor przypomina biblijny cytat: „Ojcze, dziękuję Ci, że ukryłeś te rzeczy przed mędrcami, aby objawić je pokornym i małym” (Mt 11, 25) i dodaje: „ta nota biograficzna wyjawi w końcu to, co siostra Katarzyna tak skrupulatnie ukrywała, aby spełniła się obietnica naszego Pana, że ten, kto się uniża, będzie wywyższony" ${ }^{29}$.

\section{Opinia świętości}

Dzięki biografii z 1878 roku Katarzyna Labouré wkroczyła w historię publicznej recepcji objawień z rue du Bac, jednak proces interpretacji jej po-

\footnotetext{
26 Tamże, s. 35.

27 Tamże.

28 Tamże, s. 47.

29 Tamże, s. 52. Por. Łk 14, 11.
} 
staci nie kończy się na dziele Chevaliera. Jej proces beatyfikacyjny rozpoczyna się w 1896, a zakończony zostaje w 1933 roku, w którym również ks. Lucien Misermont wydaje Niezwykłe łaski bł. Katarzyny Labouré, Siostry Miłosierdzia, wizjonerki od Cudownego Medalika. To już jego trzecie dzieło poświęcone Katarzynie ${ }^{30}$. Misermont w swoich publikacjach, nazywanych przez Réné Laurentina "hagiografiami apologetycznymi” ${ }^{31}$, stopniowo przenosi zainteresowanie z objawień i Cudownego Medalika na życie Katarzyny. Należy podkreślić, że co prawda to Chevalier opublikował po raz pierwszy życiorys Katarzyny, jednak zrobił to przede wszystkim po to, aby rozszerzyć perspektywę Notice historique Aladela. Natomiast dla Misermonta życie wizjonerki staje się tematem samym w sobie, co bez wątpienia spowodowane było także jej beatyfikacją. Katarzyna wychodzi z cienia, a przyczyną zainteresowania jej życiem staje się ona sama, nie tylko jej duchowe doświadczenia - objawienia maryjne czy Cudowny Medalik - które zaczynają być traktowane jako owoce świętości całego jej życia.

Misermont czerpie z publikacji Chevaliera, która kończy się wraz z opisem śmierci Katarzyny, ale, co ciekawe, rozszerza ją także o późniejsze wydarzenia. Opisuje pogrzeb Katarzyny, który zgromadził dużą liczbę wiernych $^{32}$ oraz pokazuje, że opinia o jej świętości rozprzestrzeniała się zwłaszcza na poziomie lokalnym za sprawą sióstr i Dzieci Maryi, jeszcze przed publikacją biografii z 1878 roku. Przytacza między innymi pierwsze świadectwo cudu dokonanego za wstawiennictwem Katarzyny:

Jedna z sióstr domowniczek, która opiekowała się ubogimi, wyszła jak zwykle, aby odwiedzić biednych z sąsiedztwa. Przed ich drzwiami, w prymitywnie przymocowanej do dwóch kółek skrzyni, której widok napełniał litością, siedział chłopiec w wieku dziesięciu lub dwunastu lat, od urodzenia, jak mówiono, bezwładny we wszystkich kończynach ${ }^{33}$.

30 Pierwsze dotyczyło przede wszystkim faktów historycznych z jej życia, a drugie, jej cnót. Jednak to właśnie trzecia pozycja poszerza rozumienie łask gratis datae, których depozytariuszką była Katarzyna: wizji i objawień, w tym tych dotyczących przyszłości, aktywnej działalności w Zgromadzeniu i poza nim oraz gloryfikacji po śmierci. L. Misermont, La bienheureuse Catherine Labouré, fille de la Charité, et la Médaille miraculeuse. Documents, aperçu critique, Paris 1933; L'âme de la bienheureuse Catherine Labouré, fille de la Charité et quelques circonstances moins connues des apparitions de la Médaille miraculeuse, Paris 1933.

31 R. Laurentin, Vie de Catherine Labouré, t. 1, dz. cyt., s. 318.

32 L. Misermont, Les grâces extraordinaires, dz. cyt., s. 189.

33 Tamże, s. 190. 
Siostra wpada na pomysł, by spuścić chłopca na grób Katarzyny, znajdujący się w Reuilly:

Bardzo szybko i nie bez emocji uniesiono pokrywę wejścia do piwnicy, która znajdowała się bezpośrednio nad czczonym grobem. Dziecko należało jednak przewiązać linami pod pachami, aby móc delikatnie zsunąć je na trumnę. Mały do tej pory nic nie mówił i pozwalał na wszystko... Czyż jednak nie jadł i nie pił swobodnie, rozpieszczony tak jak nikt inny z jego rodziny! Ale kiedy chciano przełożyć sznury pod jego biednymi ramionami, zaczął odmawiać, protestować, wić się, jak tylko potrafił, a nawet - według zapewnień jednego ze świadków w procesie beatyfikacyjnym - mówić słowa niegodne świętości miejsca, w którym się znajdował, ale przejdźmy ponad tym. Dla większego dobra, użyto jedynie trochę siły, i to z łagodnością. Gdy tylko stopy chłopca - biedne, wiszące i niepozorne podobnie, jak jego nędzne nogi - dotykają trumny, w jednej chwili sztywnieją. Nogi, ale także całe ciało, wzmacniają się. Dziecko zostaje natychmiast i całkowicie wyleczone! $!^{34}$

W ten właśnie barwny sposób Misermont opisuje pierwszy cud dokonany za wstawiennictwem Katarzyny Labouré. Jak zauważa:

Cuda mnożyły się prawie wszędzie, głównie w domach Sióstr Miłosierdzia. [...] W czasie ekshumacji pięćdziesiąt osiem ekswotów przytwierdzonych do ścian sklepienia poświadczało, że od 1877 roku wielu ludzi modliło nad tym grobem, pobudzającym do wielkiej ufności ${ }^{35}$.

Cuda zajmują również ważne miejsce $\mathrm{w}$ dokumentach procesu beatyfikacyjnego Katarzyny. Pewna siostra poświadczyła listem z 14 stycznia 1880 roku, „że została wyleczona z egzemy opornej na wszelkie lekarstwa po dwóch nowennach skierowanych do Maryi Niepokalanej za pośrednictwem Sługi Bożej”36, przy której grobie modliła się wspólnota sióstr. Znana jest również historia siostry Joséphine z Azylu dla Małych Sierot w Ménilmontant, która w styczniu 1880 roku zaświadczyła w liście, że

34 Tamże, s. 190-191.

35 Tamże, s. 191-192.

36 Cyt. za: R. Laurentin, Catherine Labouré et la Médaille miraculeuse, t. 2, dz. cyt., n 875, s. 190. 
„została wyleczona z poważnych następstw zapalenia opłucnej po modlitwach kilku sióstr odmawianych za nią przy grobie Sługi Bożej”37.

Warto dodać, że w czasie procesu beatyfikacyjnego zeznawał także Chevalier, naoczny świadek rodzącej się opinii świętości Katarzyny:

Od śmierci aż do teraz, jej grób był zawsze celem pobożnych pielgrzymek i wiele osób twierdzi, że otrzymało tam szczególne łaski. Przyznaję nawet, że kilka razy nabożnie modliłem się przy grobie pokornej Sługi Bożej. Pięćdziesiąta rocznica objawień Cudownego Medalika obchodzona 27 listopada 1880 roku, a zwłaszcza Oficjum Cudownego Medalika nadane przez Stolicę Apostolską w 1894 roku, w szczególny sposób przyczyniły się do tego, że Sługa Boża stał się znana i czczona. Możemy dodać, że mała Ilustrowana Notatka o Cudownym Medaliku, która w skrócie przedstawia historię życia Siostry Katarzyny Labouré, rozprowadzona w ponad 400 ooo egzemplarzy, jeszcze bardziej zwiększyła publiczne oddawanie czci jej pamięci ${ }^{38}$.

Powyższe przykłady wyraźnie pokazują, że po śmierci Katarzyna cieszyła się nabożną czcią wiernych, którzy wraz z Siostrami Miłosierdzia modlili się przy jej grobie w Reuilly. Misermont podkreśla, że grób wizjonerki był celem pielgrzymek, rozszerzając tym samym liczbę miejsc związanych z kultem objawień przy rue du Bac o kapliczkę w Reuilly, która dołączyła do kościoła Notre-Dame des Victoires i samej kaplicy Domu Macierzystego Sióstr Miłosierdzia, otwartej dla pielgrzymów z okazji pięćdziesiątej rocznicy objawień. Z kolei zeznanie Chevaliera z procesu beatyfikacyjnego wymienia jeszcze dwa elementy, które spopularyzowały postać siostry i przyspieszyły jej drogę na ołtarze: wprowadzenie do kalendarza liturgicznego dnia 27 listopada jako święta Najświętszej Maryi Panny Niepokalanej objawiającej Cudowny Medalik oraz ukazanie się broszury z życiorysem Katarzyny jego autorstwa.

Misermont relacjonuje jeszcze jedno ważne wydarzenie z przygotowań do beatyfikacji Katarzyny, która miała miejsce 28 maja 1933 roku, tzn. ekshumację jej ciała:

37 Tamże.

38 Por. tamże, n 928, p. 248. 
Trociny są ostrożnie usuwane, a nienaruszoną osłonę, ledwie lekko wilgotną, można łatwo pociągnąć w prawo i w lewo. Obecni na sali nieliczni szczęśliwi świadkowie patrzą z ogromną uwagą. Od razu zdają sobie sprawę, że pod dobrze zachowanym ubraniem ciało pozostało nietknięte ${ }^{39}$.

Niewątpliwie, nienaruszone ciało Katarzyny stanowiło swego rodzaju potwierdzenie jej świętości. Na przestrzeni wieków wielu świętych otrzymało ten niewątpliwy znak łaski: Katarzyna ze Sieny, Filip Nereusz, Teresa z Avila, Bernadetta Soubirous czy Jan Maria Vianney. Jednak to nie pośmiertny stan ciała Katarzyny był według biografa szczególnym dowodem świętości, lecz opinie o jej wypełnionym służbą życiu oraz opowieści naocznych świadków, mówiące o cudach dokonanych za jej wstawiennictwem, które poznano w trakcie procesu beatyfikacyjnego.

Kolejny biograf Katarzyny - ks. Edmond Crapez - w opublikowanej już po jej kanonizacji książce Przesłanie serca Maryi do Świętej Katarzyny Labouré $^{40}$, w ostatnim rozdziale zatytułowanym Święta Katarzyna Labouré, wierna Posłanniczka Serca Maryi ponownie przedstawia życiorys wizjonerki. Przywołuje także dwa cuda dokonane za wstawiennictwem Katarzyny, które otworzyły drogę do jej kanonizacji.

Pierwszy cud z 1933 roku dotyczy uzdrowienia Joséphine Coudret dotkniętej tak ciężką asystolią i towarzyszącą jej niewydolnością nerek, że bezradni lekarze poinformowali ją o niechybnie zbliżającej się śmierci. Jednak od 15 do 20 czerwca 1933 roku odprawiano w jej intencji nowennę za wstawiennictwem błogosławionej Katarzyny i chora została całkowicie uzdrowiona. Lekarze stwierdzili, że nie są w stanie wyjaśnić tego faktu z punktu widzenia ówczesnej medycyny ${ }^{41}$.

Drugi cud miał miejsce w 1937 roku i dotyczył uzdrowienia Siostry Miłosierdzia Irène Pascal cierpiącej na zrosty. Po czterech operacjach lekarze ocenili jej stan jako bezpośrednio zagrażający życiu. Bóle powiększały się i powoli tracono nadzieję na uleczenie. Wieczorem 21 maja 1937 roku, w szóstym dniu nowenny za przyczyną błogosławionej Katarzyny Labo-

39 L. Misermont, Les grâces extraordinaires, dz. cyt., s. 206-207. Por. L. Misermont, L'âme de la bienheureuse Catherine Labouré, dz. cyt., s. 246. Ekshumacja ciała Katarzyny miała miejsce 21 marca 1933 roku. Zob. AFCP, 1091, Note à propos de l'exhumation du corps de la vénérable sœur Catherine Labouré, rękopis.

40 E. Crapez, Le message du Coeur de Marie à Sainte Catherine Labouré, Paris 1947.

41 Por. tamże, s. 220. 
uré, którą siostry odmawiały za Irène, chora zasnęła. Następnego ranka obudziła się, nie czując już bólu i mogąc się normalnie odżywiać. Lekarz nie znalazł żadnych śladów schorzenia ${ }^{42}$.

Mimo że Misermont i Crapez wiele uwagi poświęcają świadectwom cudów, to jednak nie tylko one świadczą o świętości Katarzyny. W czasie zeznań przed komisją diecezjalną, jej siostrzenica, Marie-Antoinette Duhamel, podkreśla inny, niezwykle istotny aspekt - Katarzyna już przed śmiercią cieszyła się doskonałą opinią, która wynikała nie z faktu otrzymania objawień, ale z życia oddanego służbie dla innych:

Wiem, że reputacja świętości, jaką Sługa Boża cieszyła się za życia, trwała, a nawet wzrosła po jej śmierci. Za jej życia nikt nie mówił o objawieniu Najświętszej Maryi Panny, którym była uhonorowana, ale gdy tylko umarła, wieść ta rozprzestrzeniła się wszędzie. Matka przełożona i kilka Sióstr powiedziały: „Moje drogie dziecko, twoja ciotka była świętą. To ona ujrzała Najświętszą Dziewicę". Wszędzie, gdzie się udaję, kiedy ludzie dowiadują się, że jestem siostrzenicą Siostry Katarzyny Labouré, nie przestają mi mówić: „Och! jak bardzo musisz być szczęśliwa, że jesteś siostrzenicą świętej” ${ }^{43}$.

Widać zatem wyraźnie, że w biografiach Katarzyny powoli krystalizuje się opinia o jej świętości, w której nierozerwalnie łączą się dwa elementy: święte życie oddane służbie ubogim i otrzymane przy rue du Bac objawienia. Prace Misermonta i Crapeza przybliżają ten charakterystyczny dla czasów jej beatyfikacji i kanonizacji sposób interpretacji, choć należy podkreślić, że obaj autorzy wiele uwagi poświęcają również opinii o świętości Katarzyny, jaka panowała tuż po jej śmierci. Jednocześnie wszyscy biografowie próbują odpowiedzieć na pytanie, w jaki sposób można mówić o jej życiu i świętości? Zgodnie z dokumentami papieskimi świętość Katarzyny wynika z heroiczności jej cnót, zwłaszcza pokory, a także z wypełnienia misji Siostry Miłosierdzia w duchu św. Wincentego a Paulo. Jednak bez wątpienia tym, co pozwoliło ją poznać szerszej publiczności i na co zwracał uwagę Chevalier, były objawienia, a więc fakt, że została wybrana na powierniczkę Najświętszej Maryi Panny. W interpretacjach postaci

42 Por. tamże.

43 Cyt. za: R. Laurentin, Catherine Labouré et la Médaille miraculeuse, t. 2, dz. cyt., nº 928, s. 248. 
Katarzyny, zwłaszcza w jej pierwszych biografiach, opisujących wydarzenia do momentu kanonizacji, istnieje ukryte napięcie między zawoalowaną częścią jej życia jako wizjonerki, a misją pokornej służby ubogim. Dla biografów elementem łączącym te dwie rzeczywistości był sekret, który Katarzyna zachowała aż do końca życia - nie ujawniła swojej tożsamości nawet na prośbę arcybiskupa Paryża.

\section{Sekret Katarzyny}

Podczas procesu beatyfikacyjnego Chevalier nazywa sekret Katarzyny niemal heroicznym:

Wydaje mi się, że można uznać za cnotę zakrawającą na heroizm to, że przez całe swoje życie zachowywała sekret o nadprzyrodzonych przekazach otrzymywanych od Boga. Widziała, jak Cudowny Medalik rozprzestrzenia się wszędzie i dokonuje wielu cudów, widziała, jak mnożą się liczne wydania książek o nim, w których przypisywano jej, choć nie wymienionej z nazwiska, tę niezwykłą łaskę. Wydaje się, że tkwi w tym więcej niż zwyczajna pokora, niespotykana dyskrecja, a nawet można powiedzieć bardzo szczególna łaska od Boga ${ }^{44}$.

Nieco dalej Chevalier wraca do tej kwestii:

Ilekroć miałem okazję ją odwiedzić, wydawało mi się, że zauważam Służebnicę Boga cieszącą się szacunkiem, zaufaniem i uczuciem swoich towarzyszek. A jednak nie było wiadomo, że to ona jest uprzywilejowaną Siostrą, która otrzymała wizję Cudownego Medalika. Wielu ją podejrzewało, ale inni w żadnym wypadku w to nie wierzyli ${ }^{45}$.

Sekret ten staje się z czasem swego rodzaju wyróżnikiem Katarzyny, do tego stopnia, że potwierdza to nawet oficjalne przemówienie $z$ jej beatyfikacji:

44 Tamże, n 881, s. 207.

45 Tamże. 
Pośród niezwykłego poruszenia, które wytworzyło się podczas wykonywania poleceń objawionych przez Najświętszą Dziewicę, Czcigodna Sługa Boża okazała niezwykle zaskakującą pokorę. Relacjonując objawienia oraz przekazując polecenia Najświętszej Maryi Panny, zachowała ona o sobie najgłębsze milczenie i przez czterdzieści sześć lat nie pozwoliła ujawnić ani nawet wypowiedzieć swojego imienia ${ }^{46}$.

We wstępie do swojej książki Misermont podkreśla tę dobrowolną anonimowość Katarzyny: „Podczas swojego długiego siedemdziesięciodwuletniego życia będzie posiadała coś szczególnego, coś, co odróżnia ją od dużej liczby świętych, wizjonerów i wizjonerek: nie będzie znana nikomu poza swoim spowiednikiem" ${ }^{47}$. Również Crapez przywołuje sekret Katarzyny jako istotny element jej świętego życia. W tym celu cytuje przemówienie papieża Piusa XI: „Wszyscy mówią o Cudownym Medaliku, o dokonanych za jego sprawą cudach, a jednak wokół tej wybranej duszy, która była jego depozytariuszką, panuje kompletna cisza"48.

Crapez, który był zaangażowany w proces kanonizacyjny Katarzyny, zakończony uroczystą proklamacją jej świętości 27 lipca 1947 roku, przytacza tekst dekretu de tuto z 1946 roku, w którym tajemnica Katarzyny została zaprezentowana jako przejaw ogromnej pokory wizjonerki:

Ponieważ źródłem wszelkiego zła jest pycha, Błogosławiona Katarzyna z największą energią walczyła z próżną chwałą, na którą z łatwością mogła być wystawiona ze względu na niezwykłe dary, jakimi została ubogacona przez Najświętszą Dziewicę. Zwłaszcza ze względu na objawienia, podczas których w 1830 roku, jak podaje, otrzymała polecenie wybicia Medalika. Walczyła z pychą ze wszystkich swych sił nawet w tym, co najbardziej ukryte, zachowując głębokie milczenie na temat otrzymanych darów przez czterdzieści siedem lat ${ }^{49}$.

Milczenie Katarzyny staje się tematem samym w sobie. Książka Colette Yver Sekretne życie Katarzyny Labouré z 1936 roku kończy się taką oto mod-

46 L. Misermont, Les grâces extraordinaires, dz. cyt., s. 224.

47 Tamże, s. 16.

48 E. Crapez, Le message du Coeur de Marie à Sainte Catherine Labouré, dz. cyt., s. 218.

49 Tamże, s. 222. 
litwą: „Siostro Katarzyno, która przez siłę sekretu zachowanego przez całe życie dałaś ludowi chrześcijańskiemu przykład niezrównanej pokory, bądź dla nas lekcją w tym nieszczęsnym wieku pychy i braku odwagi. Amen"50.

Podobnie w pracy Marie-Thérèse Louis-Lefebvre pojawia się inna modlitwa za wstawiennictwem Katarzyny Labouré, nazywanej Świętą Milczenia: „Droga Święta Katarzyno, o Milcząca, spraw abyśmy usłyszeli Twoją naukę. Twoje rzadko wypowiadane słowa nigdy nie cytują Nowego Testamentu, ani św. Pawła, jednak nie ma takiej linijki w tych Pismach, której nie zastosowałabyś pokornie w swym życiu" ${ }^{51}$.

To właśnie w pierwszej połowie Xx wieku na dobre kształtuje się obraz św. Katarzyny, który znamy obecnie. Ponciano Nieto, hiszpański misjonarz św. Wincentego a Paulo, czerpiąc z prac swoich poprzedników, zdaje się podzielać ideę zjednoczenia w życiu Świętej misji na rzecz ubogich z łaską objawień. W swojej książce z 1933 roku ukazuje bardzo zwyczajne życie Katarzyny w służbie właściwej dla jej Zgromadzenia, życie, któremu towarzyszą niezwykłe łaski, niewidoczne na pierwszy rzut oka ${ }^{52}$. W ten sposób czytelnicy dowiadują się, że doświadczenie nadprzyrodzonego porządku nie sprzeciwia się prostej pracy z osobami starszymi lub obowiązkom domowym powierzonym Katarzynie w czasie jej pobytu w Reuilly. Nacisk zostaje zatem położony na pokorę siostry, która otrzymując objawienia pozostaje przede wszystkim służebnicą ubogich. Będzie to główna linia interpretacji postaci Katarzyny we wspólnotach wincentyńskich.

Podobnie przedstawił Katarzynę Joseph I. Dirvin, amerykański misjonarz, publikując w 1958 roku kolejną jej biografię, która aż do tej pory stanowi odniesienie dla czytelników anglojęzycznych ${ }^{53}$. Praca Dirvina, nazwana przez Josepha A. Skelly’ego „biografią kompletną”, kontynuuje linię zgodności między niezwykłymi objawieniami a zwykłą pracą przy zachowaniu anonimowości. Autor podkreśla również wkład Aladela w szerzenie przesłania objawień i jego zmagania z licznymi związanymi z tym

50 C. Yver, La vie secrète de Catherine Labouré, Paris 1936, s. 249-250.

51 M.-Th. Louis-Lefebvre, Le silence de Catherine Labouré, Paris 1950, s. 206.

52 Por. P. Nieto, La Beata Catalna Labouré y la Medalla Milagrosa, Madrid 1933, s. 234. A także na s. 2: „Nawet po tym, jak ta pokorna córka św. Wincentego a Paulo została wyniesiona aż do poznania tajemnic w porządku nadprzyrodzonym, całe jej życie pozostało proste i zwyczajne".

53 J. I. Dirvin, Saint Catherine Labouré of the Miraculous Medal, Charlotte 1984. Pierwsze wydanie pochodzi z 1958 roku, najnowsze są nadal dostępne w amerykańskich księgarniach. 
trudnościami. Ponadto wyobraża on sobie życie Katarzyny, gdyby tajemnica została ujawniona - według niego skończyłoby się to bardzo źle dla wizjonerki z powodu „katastrofalnych skutków popularności” ${ }^{54}$. Tajemnica chroniła ją i pozwalała prowadzić prosty, cichy i pracowity styl życia. Krótko mówiąc, dyskrecja była dla Dirvina znakiem pokory i jednocześnie błogosławieństwem chroniącym tę skromną Siostrę Miłosierdzia.

\section{Katarzyna lub zwyczajna świętość}

Dirvin obszernie omawia „noc ciemną”, której doświadczyła Katarzyna, próbując zachować wizerunek Dziewicy z globem jako ważną część objawień. Według autora, kierującego się klasycznymi etapami życia duchowego: oczyszczeniem, oświeceniem i zjednoczeniem, był to okres oczyszczenia wizjonerki ${ }^{55}$. Katarzyna połączyła w nim dwa aspekty: sprzeczności, które napotkała w przekazywaniu objawień, oraz niestrudzoną służbę ubogim, którą Dirvin określił jako umartwienie zwykłego życia ${ }^{56}$.

Biografia pióra Dirvina, zdecydowanie mniej hagiograficzna niż prace jego francuskich poprzedników, została napisana żywym stylem i miała na celu przybliżenie życia Katarzyny, oscylującego między niezwykłością a zwyczajnością. Jego refleksje teologiczne, takie jak ta o nocy ciemnej, są częścią biograficznej narracji. Dirvin pozostaje także dość krytyczny wobec Świętej - nie ukrywa bowiem jej trudnego charakteru. Aby wzbogacić swój tekst, posługuje się dialogami pochodzącymi ze świadectw wspólnoty oraz cytuje listy Katarzyny napisane do siostry ${ }^{57}$.

Dirvin omawia także nawrócenie Alphonse’a Ratisbonne’a oraz historię ks. Desgenette’a, który powołał do życia pierwsze stowarzyszenie związane z Cudownym Medalikiem ${ }^{58}$. Przedstawia również przepowiednie Katarzyny dotyczące wydarzeń historycznych, w tym Komuny Paryskiej, której poświęcony został osobny rozdział ${ }^{59}$. Wszystko po to, by ująć jej życie w jak najszerszym kontekście.

54 Tamże, s. 105.

55 Por. tamże, s. 125.

56 Por. tamże, s. 130.

57 Por. tamże, np. s. 136 i 139.

58 Por. tamże, s. 122 i 166-171.

59 Tamże, s. 188-208. 
René Laurentin, autor najobszerniejszej biografii Katarzyny, dąży do tego samego celu w swojej dwutomowej pracy z 1980 roku. Poprzedza ją dokładnymi badaniami, rozpoczętymi w 1971 roku i zakończonymi publikacją chronologicznego zapisu dokumentów dotyczących objawień i życiorysu Świętej. Biografia, która wypełnia pierwszy tom publikacji, została poszerzona o zbiór „dowodów” ${ }^{60}$. Każdy temat odpowiada na konkretne pytanie dotyczące historii wizjonerki, podając niezbędne odniesienia i często przytaczając niepublikowane teksty, które stanowią osobny, drugi tom. Laurentin zredagował również popularyzatorską wersję pracy, która pozostaje jedyną biografią dostępną obecnie we francuskich księgarniach ${ }^{61}$.

Według Laurentina dla Katarzyny Labouré, podobnie jak dla Bernadetty Soubirous, „objawienia nie były ani punktem wyjścia, ani dotknięciem czarodziejskiej różdżki, ale nagłym blaskiem świętości, która od dzieciństwa trwała ukształtowana w jej głębi. Jeśli nawet wchodzi ona na górę Tabor, to musi potem z niej zejść i odnaleźć Krzyż"62.

Co ważne, po wnikliwej analizie dokumentów, autor podkreśla, że jego francuscy poprzednicy mieli skłonność do bagatelizowania trudności, jakie napotykała Katarzyna i absolutyzowania jej sekretu, który dla Laurentina stanowi raczej interpretacyjną kwestię przejścia „od absolutnej tajemnicy do zwykłej dyskrecji"63. Ta prosta dyskrecja była możliwa, ponieważ siostra „nie odpowiadała obrazowi wizjonerki lub świętej, do którego przywykliśmy. Nie była nikim szczególnym. Krótko mówiąc, jej prostota wprawiała w zakłopotanie" ${ }^{\prime 4}$. Sama Święta nie wpisuje się zatem w stereotyp mistyczki, jednak doskonale wypełnia powołanie Siostry Miłosierdzia do służby ubogim.

Laurentin przedstawia również przeszkody, które Katarzyna napotkała nie tylko w swoim życiu, ale także w recepcji jej postaci we wspólnocie misjonarzy św. Wincentego a Paulo. Opisuje sprzeciw, który Pierre Coste wyraził wobec uznania świętości wizjonerki w swoich tajnych wspomnie-

6o R. Laurentin, P. Roche, Catherine Labouré et la Médaille miraculeuse, t. 1: Documents authentiques (1830-1876), Paris 1976; R. Laurentin, Catherine Labouré et la Médaille miraculeuse, t. 2: Procès de Catherine (1877-1900), dz. cyt.; R. Laurentin, Vie de Catherine Labouré, t. 1, dz. cyt.;

R. Laurentin, Vie de Catherine Labouré, t. 2, dz. cyt.

61 R. Laurentin, Petite vie de Catherine Labouré, Paris 2017.

62 R. Laurentin, Vie de Catherine Labouré, t. 1, dz. cyt., s. 318.

63 R. Laurentin, Vie de Catherine Labouré, t. 2, dz. cyt., przypis 89, s. 286.

64 Tamże, s. 287. 
niach z początku XX wieku. Były one bardzo krytyczne wobec samej siostry i przede wszystkim zaprzeczały wizji Maryi z globem, a także określały przepowiednie Katarzyny jako „rozczarowujące”. Jednak krytyka Coste nie została upubliczniona za jego życia, nawet jego list wysłany do Rzymu jako votum separatum wobec kanonizacji Katarzyny nie został opublikowany $^{65}$. Historia ta dowodzi jednak, że postać Katarzyny nie zawsze była postrzegana jednakowo. Laurentin, przedstawiając ten nieznany dotąd aspekt, znacznie poszerzył zakres badań nad jej życiem, wskazując równocześnie na apologetyczny charakter prac poprzedników.

Laurentin, co oczywiste, relacjonuje trzy objawienia z 1830 roku oraz inne doświadczenia duchowe Katarzyny, przede wszystkim jednak jako pierwszy dokładnie opowiada o jej codziennym życiu w Reuilly, a także o wygnaniu spędzonym w Ballainvilliers podczas Komuny Paryskiej, gdy była zmuszona opuścić stolicę ${ }^{66}$. Co ciekawe, Laurentin wykorzystuje również świadectwa Sióstr, ale nie po to, by jak jego poprzednicy udowodnić heroizm cnót Katarzyny, lecz by spisać jej historię utrwaloną w pamięci wspólnoty. Jego narracja jest bogata w szczegóły i poświęca wiele miejsca zwykłym zadaniom Świętej: pracy w gospodarstwie rolnym ${ }^{67}$, opiece nad starszymi osobami, podopiecznymi sióstr w Reuilly ${ }^{68}$, jej rekolekcjom duchowym, a także troskom życia we wspólnocie ${ }^{69}$. Wszystko to przeplata się ze stopniowym rozpowszechnianiem Cudownego Medalika, historią nawrócenia Ratisbonne’a i wydarzeniami historycznymi: rewolucją 1830 i 1848 roku oraz Komuną Paryską.

65 Por. R. Laurentin, Vie de Catherine Labouré, t. 1, dz. cyt., s. 318. Niepublikowany tekst Coste'a: Archives de la Congrégation de la Mission, Paris, Étude critique par P. Coste, rękopis, 7 stron, 1930. Autor odróżnia tu Cudowny Medalik jako skuteczne narzędzie ewangelizacyjne od jego pochodzenia, które jego zdaniem nie może być określone jako nadprzyrodzone jedynie w oparciu o zeznania jednego świadka. Ponadto według Coste’a wizje Krzyża oraz przepowiednie Katarzyny mają charakter jedynie relektury historii o mistycznym zabarwieniu. Laurentin w swojej pracy szeroko polemizuje z Costem i podważa jego argumenty. Por. R. Laurentin, P. Roche, Catherine Labouré et la Médaille miraculeuse, t. 1, dz. cyt., s. 32-37. Warto również zaznaczyć, że w 1930 roku Coste publikuje artykuł poświęcony tematowi objawień z okazji ich stulecia, artykuł, w którym przedstawia Katarzynę w pozytywnym świetle, całkowicie zatajając przed czytelnikami swoje wątpliwości: P. Coste, La Médaille miraculeuse, „Annales de la Congrégation de la Mission” 95 (1930), s. 433-564.

66 Por. R. Laurentin, Vie de Catherine Labouré, t. 1, dz. cyt., s. 228.

67 Por. tamże, s. 126.

68 Por. tamże, s. 134.

69 Por. tamże, s. 165. 
W ten sposób Laurentin maluje barwny portret wizjonerki z rue du Bac, w którym pierwszeństwo zyskuje zwyczajność życia, a nie tajemnica osnuwająca spotkania z Maryją. Nacisk zostaje położony na biografię wierną i daleką od patetyzmu, w której przedstawia się nowy typ świętości „bez chwały i tryumfalizmu" ". Katarzyna, wypełniając powołanie prostej wiejskiej kobiety, „niepiśmiennej do 18 roku życia, która w 1830 roku została wybrana jako prorocze narzędzie odnowy, stała się realizacją słów Chrystusa: «Dziękuję Ci, Ojcze, za to, co ukryłeś przed mądrymi i uczonymi, a co objawiłeś prostaczkom» (Mt 11, 25)"71.

W tej samej linii można zinterpretować wprowadzenie do małej książeczki z 2005 roku, wydanej przez siostrę Anne Prévost, które ma formę listu do Katarzyny:

Droga Święta Katarzyno,

wiemy, że nie chciałabyś, aby twoje zdjęcie znalazło się na pierwszej stronie, Ty, którą tak często nazywa się Świętą Milczenia. Zrobiliśmy to jednak, ponieważ Twoje świadectwo jest wielką nadzieją dla ludzi naszych czasów, a zwłaszcza dla najbardziej pokrzywdzonych na naszej ziemi, których tak bardzo kochałaś i którym tak bardzo służyłaś. Dziękujemy za Twoją wyrozumiałość, dziękujemy za cierpliwość do nas, którzy jesteśmy jeszcze w drodze.

Dziękujemy za uczenie tych wszystkich, którzy podążają za Tobą, całkowitego zaufania Bogu Ojcu i Niepokalanej Dziewicy Maryi.

Dziękujemy, że wzbudziłaś w nas pragnienie odpowiedzi na wezwanie Jezusa, łącząc się ze wszystkimi, którzy byli i pozostają Twoimi przyjaciółmi: ubogimi w ubóstwie wszelkiego rodzaju.

Dziękujemy Ci za Twoją pokorną, codzienną wierność, bez egzaltacji i zbędnych słów, wierność, która czyni Twoje życie cudownym, to znaczy życiem, w którym Bóg ukazuje cuda przebaczenia i czułość.

Twoi wdzięczni przyjaciele ${ }^{72}$.

70 R. Laurentin, Vie de Catherine Labouré, t. 2, dz. cyt., okładka, s. 4.

71 R. Laurentin, Vie de Catherine Labouré, t. 1, dz. cyt., s. 320.

72 A. Prévost, Catherine Labouré. La Messagère du Ciel, Strasbourg 2006, s. 3. 
Co interesujące, w tym krótkim tekście Prévost kładzie duży nacisk na służbę ubogim, a przy tym nie wspomina o objawieniach. W dalszej części tekstu Katarzyna zostaje ukazana nie tylko jako „widząca, ale przede wszystkim wierząca"73, ta, która „wciąż mówi nam dzisiaj, że świętość jest czymś możliwym dla każdego, jeśli tego pragniemy" ${ }^{74}$. Natomiast jeśli chodzi o objawienia, to "nie są one tylko jakimś nawiasem w życiu Katarzyny, ale są światłem dla jej życia wypełnionego służbą"75.

Podsumowując, możemy powiedzieć, że w historii odbioru życia Katarzyny następuje przesunięcie akcentów. W 1878 roku Katarzyna zostaje oficjalnie przedstawiona jako wizjonerka $\mathrm{z}$ rue du Bac, wypełniając w ten sposób jedną z luk w rozpowszechnionej przez Aladela wersji objawień. Głównym tematem tej publikacji są właśnie objawienia i ich owoc - $\mathrm{Cu}$ downy Medalik - oraz opisy łask, a nie osoba Siostry. I choć w części pierwszych biografii, szczególnie w okresie beatyfikacji i kanonizacji, akcentowane są cuda za jej wstawiennictwem, z biegiem lat to życie Katarzyny samo w sobie staje się wiodącym tematem, wpisując się w nurt licznych biografii świętych.

$\mathrm{Na}$ tę zmianę w perspektywie postrzegania Katarzyny z pewnością wpłynął nowy model świętości - taki, w którym staje się ona dostępna dla każdego człowieka, a to, co zwyczajne i codzienne, zastępuje to, co niezwykłe. W ten sposób Siostra Katarzyna Labouré pozostaje wizjonerką z rue du Bac i jednocześnie świętą jako dyskretna służebnica ubogich.

Poznając postać Katarzyny poprzez jej biografię, warto zastanowić się, które elementy życiorysu tej skromnej Siostry Miłosierdzia są dziś dla nas ważne? Które pomijamy, a na które zwracamy uwagę? ${ }^{76}$ Odpowiedzi mogą stać się dobrą wskazówką, która pomoże odkryć własną drogę prowadzącą do świętości.

73 Tamże, s. 16.

74 Tamże, s. 18.

75 Tamże, s. 10.

76 Przy tej okazji zachęcamy Czytelnika do poszerzenia wiedzy i zapoznania się z biografią Katarzyny Labouré dostępną w języku polskim: W. Rakocy, Św. Katarzyna Labouré i Cudowny Medalik, Kraków 2017. 


\section{Abstrakt}

Święta Katarzyna Labouré oczami swoich biografów

Niniejszy artykuł przedstawia najważniejsze biografie św. Katarzyny Labouré, która w 1830 roku otrzymała łaskę trzech objawień Matki Bożej. Tożsamość wizjonerki nie była jednak publicznie znana za życia. Dopiero po śmierci, 31 grudnia 1876 roku, ujawniono oficjalnie imię tej, która spotkała Maryję i przekazała światu Cudowny Medalik. Tym samym recepcja postaci Katarzyny, skromnej siostry miłosierdzia, a obecnie świętej Kościoła, rozwija się wraz z ujawnianiem kolejnych faktów z jej życia w publikacjach biograficznych m.in. Chevaliera, Misermonta, Crapeza czy Laurentina.

Słowa kluczowe: biografia, Katarzyna Labouré, objawienia maryjne, cuda, Cudowny Medalik

\section{Abstract}

Saint Catherine Labouré the in the eyes of her biographers

This article presents the most important biographies of St. Catherine Labouré, who received the grace of three apparitions of Our Lady in 1830. However, the identity of the visionary was not publicly known during her lifetime. Only after her death, on December 31, 1876, was the name of the one who met Mary and gave the Miraculous Medal to the world officially revealed. Thus the reception of the figure of Catherine, a humble Daughter of Charity and now a saint of the Church, develops as more facts about her life are revealed in biographical publications by Chevalier, Misermont, Crapez and Laurentin, among others.

Keywords: biography, Catherine Labouré, Marian apparitions, miracles, Miraculous Medal 


\section{Bibliografia}

1. Archives des Filles de la Charité, Paris (AFCP).

2. [Chevalier J.], La Médaille miraculeuse. Origine - histoire - diffusion résultats, par $M$. Aladel, [9ème] édition revue et augmentée, Paris 1878.

3. Coste P., La Médaille miraculeuse, „Annales de la Congrégation de la Mission" 95 (1930), s. 433-564.

4. Crapez E., Le message du Cour de Marie à Sainte Catherine Labouré, Paris 1947.

5. Dirvin J. I., Saint Catherine Labouré of the Miraculous Medal, Charlotte 1984 .

6. Laurentin R., Roche P., Catherine Labouré et la Médaille miraculeuse, t. 1: Documents authentiques (1830-1876), Paris 1976.

7. Laurentin R., Catherine Labouré et la Médaille miraculeuse, t. 2: Procès de Catherine (1877-1900), Paris 1979.

8. Laurentin R., Petite vie de Catherine Labouré, Paris 2017.

9. Laurentin R., Vie de Catherine Labouré. Voyante de la rue du Bac et servante des pauvres 1806-1876, t. 1: Récit, Paris 1980.

10. Laurentin R., Vie de Catherine Labouré. Voyante de la rue du Bac et servante des pauvres 1806-1876, t. 2: Preuves, Paris 1980.

11. Louis-Lefebvre M.-Th., Le silence de Catherine Labouré, Paris 1950.

12. Misermont L., La bienheureuse Catherine Labouré, fille de la Charité, et la Médaille miraculeuse. Documents, aperçu critique, Paris 1933.

13. Misermont L., L'âme de la bienheureuse Catherine Labouré, fille de la Charité et quelques circonstances moins connues des apparitions de la Médaille miraculeuse, Paris 1933.

14. Nieto P., La Beata Catalna Labouré y la Medalla Milagrosa, Madrid 1933.

15. Notice historique sur l'origine et les effets d'une nouvelle Médaille en l'honneur de l'Immaculée Conception de la très Sainte Vierge Marie, généralement connue sous le nom de la Médaille miraculeuse, 1ère édition, Paris 1834.

16. Prévost A., Catherine Labouré. La Messagère du Ciel, Strasbourg 2006.

17. Rakocy W., Św. Katarzyna Labouré i Cudowny Medalik, Kraków 2017.

18. Yver C., La vie secrète de Catherine Labouré, Paris 1936. 
Aniwersytet Papieski

ifl Jana Pawta II

(b) wrakowie 